\title{
Rak piersi - znaczenie profilaktyki pierwotnej i wtórnej
}

\author{
Joanna Tkaczuk-Włach ${ }^{1}$, Małgorzata Sobstyl' ${ }^{1}$, Grzegorz Jakiel ${ }^{2}$ \\ ${ }^{1}$ Katedra i Klinika Ginekologii i Endokrynologii Ginekologicznej Uniwersytetu Medycznego w Lublinie \\ ${ }^{2}$ Klinika Położnictwa i Ginekologii, Centrum Medyczne Kształcenia Podyplomowego w Warszawie \\ Przegląd Menopauzalny 2012; 4: 343-347
}

Rak piersi jest najczęściej występującym nowotworem złośliwym wśród kobiet w Polsce. Rocznie z jego powodu umiera w naszym kraju ok. 5000 kobiet. Rak piersi jest drugą - po raku płuc - przyczyną zgonów Polek z powodów onkologicznych. W roku 2009 zanotowano w Polsce 15752 zachorowań na raka piersi, natomiast z powodu tego nowotworu zmarły 5242 kobiety [1].

Również w skali świata rak piersi jest uznawany za najbardziej rozpowszechniony z nowotworów - podawane są dane, wg których aż 34\% kobiet żyjących z nowotworem choruje właśnie na raka piersi [2-4]. W Polsce dane z 2009 r. wskazują, że 23\% kobiet chorujących na nowotwór w naszym kraju leczyło się z powodu raka piersi [1].

Problem dotyczy głównie kobiet mieszkających w krajach o wysokim stopniu rozwoju ekonomicznego. Według danych epidemiologicznych, w krajach rozwijających się w roku 2010 rak piersi był przyczyną zgonu 68000 kobiet w wieku 15-49 lat, podczas gdy w krajach rozwiniętych $26000[5]$.

Amerykański National Cancer Institute na podstawie badań epidemiologicznych ocenia, że ryzyko rozwoju nowotworu piersi w życiu kobiety wynosi ok. $12 \%$. Wzrasta ono przede wszystkim wraz z wiekiem kobiety. Szacowane ryzyko rozwoju w ciągu 10 lat u kobiet w wieku 40 lat wynosi 1 na 69 kobiet, w grupie kobiet 50-letnich - 1 na 42 kobiety, 1 na 29 w wieku 60 lat [6]. Ostatnio u młodych kobiet obserwuje się wzrost zachorowalności przy malejącej umieralności z powodu raka piersi. U kobiet $w$ wieku średnim wciąż obserwuje się wzrost zachorowalności przy względnie stałych współczynnikach umieralności. To właśnie z tej ostatniej grupy wywodzi się największa liczba chorych, bowiem kobiety w wieku 50-59 lat stanowią aż 32\% wszystkich pacjentek chorujących na raka piersi $[1,3,4]$

\section{Profilaktyka pierwołna}

Celem działań określanych jako profilaktyka pierwotna jest zmniejszenie zachorowalności na raka piersi. Na podstawie dzisiejszej wiedzy na temat czynników mających związek z większym ryzykiem zachorowania na raka piersi można modyfikować czy eliminować pewne niekorzystne zachowania, zwiększając prozdrowotną świadomość kobiet.
Wśród czynników ryzyka wymienia się m.in. alkohol - zwłaszcza wysokoprocentowy, dietę bogatą w tłuszcze nasycone, otyłość - zwłaszcza w wieku pomenopauzalnym i szczególnie typu brzusznego. Tymczasem dieta bogata w warzywa i owoce (wysoka podaż kwasu foliowego) oraz regularna aktywność fizyczna zdecydowanie redukują ryzyko powstania raka piersi $[3,4]$.

Wpływ czasu, w jakim na gruczoł piersiowy oddziałują hormony - szczególnie estrogeny - jest wśród czynników ryzyka uważany za szczególnie istotny. Chodzi tu o wydłużony czas ekspozycji gruczołu piersiowego na ich działanie, który jest zwiększony u kobiet, u których wystąpiła wczesna pierwsza i późna ostatnia miesiączka, nie rodziły lub późno urodziły swoje pierwsze dziecko (po 30. roku życia). Chociaż wpływ na powyższe czynniki wydaje się mało możliwy, propagowanie wczesnego macierzyństwa czy przemyślane stosowanie egzogennych hormonów w postaci hormonalnej terapii zastępczej (HTZ), szczególnie u kobiet z grup podwyższonego ryzyka, wydaje się możliwym do zrealizowania [4, 7]. Należy w tym miejscu zaznaczyć, że wpływ pigułek antykoncepcyjnych na podwyższenie ryzyka rozwoju nowotworu piersi jest tematem wielu kontrowersji i przedmiotem wielu nadal prowadzonych badań [8]. Ewentualny niekorzystny związek z rozwojem raka piersi wydaje się mieć znaczenie głównie w populacji kobiet obarczonej dużym ryzykiem genetycznym [9]. Unikanie napromieniania ma istotne znaczenie $u$ kobiet młodych. Przyjmuje się, że ok. $1 \%$ odnotowanych przypadków raka piersi miało związek ze stosowanym w celach medycznych promieniowaniem [3].

W badaniach z randomizacją udowodniono skuteczność selektywnych modulatorów receptora estrogenowego - tamoksyfenu i raloksyfenu w obniżaniu ryzyka rozwoju pierwotnego raka piersi u kobiet z grup najwyższego dziedzicznie uwarunkowanego ryzyka [4, 10, 11].

W roku 1998 Amerykańska Agencja ds. Żywności i Leków (Food and Drug Administration - FDA) zaakceptowała tamoksyfen jako lek w chemioprofilaktyce pierwotnego raka piersi. Zakwalifikowano do niej głównie kobiety zarówno w okresie przed-, jak i pomenopauzalnym z grup podwyższonego dziedzicznie uwarunkowanego ryzyka zachorowania na raka piersi $[10,11]$. Te same wskazania od 2007 r. dotyczą wg FDA raloksyfenu, jednak zakwalifikowano go do chemioprofilaktyki jedy- 
nie u kobiet z grup wysokiego ryzyka w wieku pomenopauzalnym $[10,11]$.

Tamoksyfen wykazuje zarówno właściwości estrogenowe, jak i antyestrogenowe. Indukuje apoptozę komórek i jest inhibitorem angiogenezy. Uznaje się, że tamoksyfen zapobiega rozwojowi raka piersi równie skutecznie jak profilaktyczna adneksektomia w grupie kobiet z najwyższym genetycznie uwarunkowanym ryzykiem rozwoju raka piersi $[7,12,13]$. Tamoksyfen nie zmniejsza jednak ryzyka zachorowania na raka jajnika, zwiększa natomiast nawet kilkakrotnie ryzyko zachorowania na raka błony śluzowej macicy [7, 10, 14]. Trzyletni okres stosowania tamoksyfenu w celach chemioprofilaktyki ma zabezpieczać pacjentkę-nosicielkę mutacji w genie $B R C A 1$ lub/i BRCA2 na kolejne 10 lat i powinien obejmować młode pacjentki w wieku 35.-40. roku życia. Jednak jak pokazują analizy prowadzone regularnie w USA, populacja kobiet, u której rzeczywiście stosuje się chemioprofilaktykę, stanowi tylko niewielki odsetek pacjentek, które można lub powinno się do niej zakwalifikować. Winą obarcza się tutaj nadmierny strach lekarzy nieonkologów - głównie lekarzy rodzinnych, przed ewentualnymi objawami ubocznymi czy po prostu ich brak wiedzy i doświadczenia w tym zakresie [11].

Obecnie w fazie badań klinicznych są kolejne leki o spodziewanym działaniu zmniejszającym ryzyko rozwoju raka piersi, tj. anastrazol i letrozol czy eksemestan [15].

Innym działaniem mieszczącym się $\mathrm{w}$ ramach profilaktyki pierwotnej, skierowanym do pacjentek z udowodnionym genetycznym najwyższym ryzykiem rozwoju raka piersi i jajnika, jest profilaktyczne usunięcie przydatków połączone lub nie z histerektomią, wykonywane w 35.-40. roku życia. Takie postępowanie zmniejsza ryzyko rozwoju raka piersi o 60-75\%, w znacznym stopniu ogranicza również ryzyko rozwoju raka jajnika $[7,12,13,16]$. Innym radykalnym postępowaniem jest proponowanie obustronnej profilaktycznej mastektomii, co zmniejsza ryzyko rozwoju raka piersi nawet o 90\% [7, 12]. Okazuje się, że takie postępowanie działa mimo stwierdzanego braku ekspresji receptora dla estrogenów w komórkach raka piersi u większości nosicielek mutacji genu BRCA1 $[12,14]$. Nie dziwi fakt, że radykalność wymienionych wyżej zabiegów i proponowanie ich wykonania w młodym wieku (w celu zwiększenia skuteczności) jest często bardzo trudna do zaakceptowania dla większości zakwalifikowanych kobiet.

Podsumowując, w przypadku raka piersi dzisiejsza medycyna w swoich postępowaniach zapobiegawczych jest wciąż mocno ograniczona. Etiologia większości przypadków raka wciąż pozostaje niewytłumaczona. Dlatego wszelkie działania składające się na profilaktykę wtórną - ukierunkowaną na wczesne wykrycie zmian bez manifestacji klinicznej i zmniejszenie przez to umieralności - są szczególnie uzasadnione, a budowanie świadomości prozdrowotnej wśród kobiet - warte każdego wysiłku.

\section{Profillakłyka włórna}

Badanie przesiewowe powinno mieć taką czułość, aby umożliwiać wykrywanie zmian niemych klinicznie. Takim badaniem w skriningu raka piersi pozostaje badanie mammograficzne. Jego czułość oceniana jest na 77-95\%, natomiast swoistość na 94-97\% [17].

Równie istotną wymierną korzyścią przeprowadzanego programu badań przesiewowych ma być zmniejszenie umieralności związanej z rakiem piersi [18, 19]. Formułując powyższy cel główny, należy sobie uświadomić, że wcześnie wykryty rak daje większe szanse na wyleczenie - prowadzone bardziej oszczędzającymi pacjentkę i budżet metodami. Zmniejsza również ryzyko powstania przerzutów czy wznowy, co łącznie wydłuża życie oraz poprawia jego komfort. Według przeprowadzanych w USA badań z randomizacją, wartość badania mammograficznego w obniżaniu umieralności kobiet z powodu raka piersi jest udowodniona i szacowna na ok. 15\%, zarówno w grupie kobiet młodych (39-49 lat), jak i starszych (50-59 lat) [20].

Badanie mammograficzne wykonywane jest w dwóch projekcjach - skośnej i górno-dolnej. Powszechna coraz bardziej technika cyfrowa, w porównaniu z analogową, daje możliwość szybszej diagnozy, magazynowania i przesyłania obrazów i - co ważne - ma wyższą czułość diagnostyczną w grupie kobiet o gęstej gruczołowej strukturze piersi w okresie przedmenopauzalnym lub okołomenopauzalnym. Nowa technika trójwymiarowego obrazowania piersi - tomosynteza, pozwala m.in. na unikalne nakładanie obrazu, co daje jeszcze lepsze możliwości diagnostyczne, nawet w porównaniu z mammografią cyfrową [21, 22].

Badanie mammograficzne powinno być wykonywane w ośrodkach wyspecjalizowanych, z możliwością konsultacji lekarzy kilku specjalności: radiologa, chirurga, onkologa i patomorfologa. Szacuje się, że w takim ośrodku powinno wykonywać się ok. 2000 zdjęć mammograficznych rocznie $[18,23]$.

Do niekorzystnych zjawisk towarzyszących badaniom przesiewowym należą: ból odczuwany podczas badania, lęk, wyniki fałszywie pozytywne i wynikający z tego stres pacjentki, niepotrzebne biopsje piersi [2].

Czynnikiem wpływającym na skuteczność badań profilaktycznych jest również grupa docelowa kobiet, do których dana metoda - w tym przypadku mammografia - jest kierowana. Należy tu zwrócić uwagę na znaczący wpływ budowy piersi na wynik, a raczej wiarygodność badania mammograficznego. U kobiet młodych mamy najczęściej do czynienia z tzw. gęstą strukturą piersi. Natomiast u kobiet starszych, u których większa część utkania gruczołu stanowi dobrze przepuszczalna promieniowanie rentgenowskie tkanka tłuszczowa - kontrast dla innych struktur jest znamiennie wyraźniejszy. Amerykańskie Towarzystwo Radiologiczne (American College of Radiology - ACR) opisuje 
cztery kategorie struktury gruczołu piersiowego: z przewagą tkanki tłuszczowej, włóknisto-gruczołowa, o niejednorodnej gęstości oraz tkanka wybitnie gęsta [24]. Problemem jest niejednokrotnie interpretacja zdjęć z badania gruczołu o utkaniu niejednorodnym i tkanki wybitnie gęstej.

Opis badania mammograficznego powinien również podlegać standaryzacji. Amerykańskie Towarzystwo Radiologiczne w roku 2003 opracowało system oceny BIRADS (Breast Imaging Reporting and Data System), który wyróżnia 6 kategorii wniosków końcowych w opisie mammografii. W programie przesiewowym wynik badania mammograficznego jest prawidłowy u 95\% kobiet, co odpowiada BIRADS 1 [21, 25]. Poza tym system wyróżnia zmiany wymagające dodatkowych badań obrazowych, tzw. niejednoznaczne (BIRADS 0), zmiany łagodne (BIRADS 2), zmiany prawdopodobnie łagodne (BIRADS 3), zmiany podejrzane, prawdopodobnie złośliwe, wymagające bioposji (BIRADS 4), wreszcie zmiany radiologiczne złośliwe (BIRADS 5), aż do rozpoznanego raka piersi potwierdzonego badaniem histopatologicznym (BIRADS 6; nie dotyczy badań skaningowych) [21, 25].

U.S. Preventive Services Task Force (UPSTF) w 2009 r. opublikowało zalecenia, w których rekomenduje wykonywanie badania mammograficznego piersi co 2 lata w grupie kobiet w wieku 50.-74. roku życia. Eksperci z tej grupy nie znajdują wystarczających dowodów na zalecanie mammografii kobietom w wieku 75 lat i starszych [2].

Zalecenia amerykańskich ekspertów opowiadają się również przeciwko rutynowemu wykonywaniu przesiewowych badań mammograficznych u kobiet w wieku 40-49 lat. Nie potwierdzają również wyższości badania rezonansem magnetycznym (RM) czy mammografią cyfrową nad tradycyjną mammografią jako badaniem skriningowym w profilaktyce raka piersi [2].

W Polsce prowadzony jest Populacyjny Program Wczesnego Wykrywania Raka Piersi, w którym bezpłatnym badaniem mammograficznym objęte są kobiety w wieku 50.-69. roku życia. Należy jednak zaznaczyć, że zarówno program badań przesiewowych w kierunku raka piersi, jak i szyjki macicy stał się dostępny dla kobiet w Polsce przynajmniej dwie dekady później niż w Wielkiej Brytanii czy Finlandii [26].

Polska Unia Onkologii u kobiet w wieku 50.-69. roku życia rekomenduje wykonywanie badania mammograficznego co 24 miesiące, natomiast w grupie kobiet 4049 lat wykonywanie badania mammograficznego uzależnione jest od indywidualnego szacowanego ryzyka - m.in. na podstawie wywiadu rodzinnego i objawów. Proponuje się ewentualne wykonywanie mammografii w tej grupie kobiet co 12-18 miesięcy [18]. W grupie kobiet młodych (20-39 lat) i kobiet starszych (powyżej 70. roku życia) Polska Unia Onkologii nie zaleca wykonywania badań mammograficznych [18].

Rekomendacje opracowane przez Polskie Towarzystwo Ginekologiczne (PTG) w 2005 r. zalecają wykony- wanie mammografii u kobiet w wieku 45.-50. roku życia co 2 lata, natomiast od 50 lat co rok [23].

Rekomendacje PTG z 2005 r. dotyczące profilaktyki i wczesnej diagnostyki zmian w gruczole sutkowym zwracają uwagę na konieczność zwiększenia udziału ginekologów w wykrywaniu wczesnych zmian. I tak proponuje się wykonywanie badania mammograficznego co 2 lata u kobiet w wieku 45-50 lat, natomiast u starszych co rok [23]. Kobiety obciążone rakiem sutka rodzinnie w pierwszym stopniu pokrewieństwa powinny mieć pierwsze badania mammograficzne wykonywane o 5 lat wcześniej od rozpoznania raka sutka u bliskiego krewnego.

W Rekomendacjach PTG, które dotyczą wykrywania wysokiego, dziedzicznie warunkowego ryzyka zachorowania na raka gruczołu sutkowego i/lub jajnika oraz opieki nad rodzinami, w których ono występuje, zwraca się uwagę na konieczność objęcia tych kobiet programami bardzo wczesnej opieki [16].

Jak podają polscy eksperci, bardzo wysokie i wysokie ryzyko zachorowania na raka piersi (prawdopodobieństwo zachorowania co najmniej czterokrotnie wyższe niż w populacji ogólnej) zdefiniowano wg ściśle określonych kryteriów u ok. 15\% kobiet z rozpoznaniem raka piersi, co stanowi ok. 0,5-1\% populacji [18].

Wśród zdarzeń kwalifikujących kobietę do grupy najwyższego ryzyka zachorowania na raka piersi (prawdopodobieństwo 25-80\%) są m.in.: wykrycie u chorej mutacji genu $B R C A 1$ lub $B R C A 2$, pochodzenie z rodziny obciążonej wystąpieniem raka jajnika i/ lub piersi wśród krewnych pierwszego i drugiego stopnia 3 lub więcej zachorowań, rozpoznanie u krewnych pierwszego stopnia raka synchronicznego lub metachronicznego.

Czynnikami kwalifikującymi kobietę do grupy wysokiego ryzyka zachorowania (prawdopodobieństwo 20-25\%) są m.in.: wczesne zachorowanie matki lub siostry przed 40. rokiem życia, 2 zachorowania na raka piersi i/lub jajnika wśród krewnych pierwszego i/lub drugiego stopnia (łącznie z probantką), rozpoznanie raka metachronicznego u krewnych pierwszego stopnia [18].

I tak specjaliści rekomendują u kobiet z powyższymi obciążeniami wykonywanie corocznie, od 20.-25. roku życia badania palpacyjnego i obrazowego piersi (u młodych kobiet USG), od ok. 35. roku życia powinna to być mammografia i USG i od 50. roku życia - mammografia. Podobnie jak Amerykańskie Towarzystwo Onkologiczne za najkorzystniejszą opcję, jeżeli chodzi o badania obrazowe, uznaje się w tej grupie kobiet coroczne badanie za pomocą RM. Zaleca się również od 30. roku życia coroczne: badanie ginekologiczne z badaniem USG oraz oznaczanie CA 125 w surowicy [16].

Jak podkreślają specjaliści, obecna wiedza na temat genetycznego podłoża rozwoju raka piersi wciąż jest niepełna. Wiadomo, że nosicielstwo genów, które mają silny związek z predyspozycją do zachorowania (BRCA1, $B R C A 2, T P 53)$ nie jest w ogólnej populacji zbyt częste. 
Jednak już nosicielstwo innych - słabszych, jest o wiele częstsze $[14,18]$. Wynika z tego, że dokładne zebranie wywiadu rodzinnego ma szczególne znaczenie u młodych kobiet, ponieważ jest to grupa pacjentek, wśród której należy wyselekcjonować te kobiety, u których skrining powinien zaczynać się jeszcze przed 40. rokiem życia $[16,27]$.

Tymczasem ostatnia publikacja dotycząca występowania mutacji w genie BRCA1, przeprowadzana w populacji polskiej na terenie województwa mazowieckiego, wykazała częste jej występowanie w populacji nieobciążonej wywiadem rodzinnym w kierunku występowania raka piersi. Ze względu na powyższe, autorzy proponują wykonywanie testów w kierunku mutacji w genie BRCA1 w każdym przypadku rozpoznania raka piersi, niezależnie od wieku zachorowania czy obciążenia rodzinnego [28].

Ultrasonografia gruczołów sutkowych nie jest badaniem zastępującym mammografię w skriningu. Stanowi natomiast uzupełniającą część diagnostyki adresowaną szczególnie do kobiet młodszych, z gęstym gruczołowym utkaniem piersi. Ma również kilka innych zalet - daje możliwość różnicowania zmian litych i torbielowatych, oceniania przewodów mlecznych oraz struktur leżących blisko klatki piersiowej, często słabo dostępnych w badaniu mammograficznym. Dodatkowo wprowadzana ostatnio wolumetryczna analiza ultradźwiękowa daje precyzyjne obrazy pomocne zwłaszcza przy wykonywaniu biopsji. To wszystko - przy stosunkowo małych kosztach i nienarażaniu pacjentki na promieniowanie rentgenowskie - daje spore możliwości diagnostyczne uzupełniające diagnostykę mammograficzną [21, 29].

Użycie RM w badaniu skriningowym raka piersi było opisywane już w 1980 r. Badania prowadzone w grupie kobiet dużego ryzyka wskazują, że RM charakteryzuje znacząco zwiększona czułość w porównaniu z mammografią z USG lub bez USG, jest szczególnie pomocny w wykluczaniu raka piersi [30, 31].

Dlatego podkreśla się, że tradycyjna mammografia nie jest wystarczającym narzędziem diagnostycznym wykluczającym chorobę w grupie szczególnie zagrożonej [32, 33].

Podsumowując - mimo oczywistych zalet RM ze względu na koszty i częstość wyników fałszywie dodatnich nie jest metodą skriningową skierowaną do ogólnej populacji kobiet [34]. Ma natomiast swoje istotne, często rozstrzygające znaczenie w grupie kobiet z podwyższonym ryzykiem raka piersi. Ostatnie wytyczne Amerykańskiego Towarzystwa Onkologicznego (2010 r.) zalecają wykonywanie mammografii RM raz w roku jako badanie przesiewowe $w$ kierunku raka piersi w grupie kobiet ze stwierdzoną mutacją genu BRCA1 i/lub BRCA2, po radioterapii klatki piersiowej między 10. a 30. rokiem życia oraz nosicielek mutacji genów TP53 lub PTEN [35].

Samobadanie piersi określa się często mianem nieinwazyjnego testu przesiewowego. Jednak jednym z elementów ograniczających jego skuteczność jest fakt braku regularności w jego wykonywaniu przez kobiety, co potwierdzają również polskie badania [36, 37].

Dobrze zaplanowane analizy przeprowadzone wśród kobiet przeszkolonych i wykonujących regularnie badanie piersi wykazały brak skuteczności w wykrywaniu raka piersi i - co ważne - obniżeniu umieralności z tego powodu [38, 39].

Zwraca się jednocześnie uwagę, że mimo wymiernych ograniczeń tego postępowania nauka samobadania piersi oraz regularna praktyka w badaniu i poznawaniu własnych piersi motywuje kobiety do myślenia o własnym zdrowiu i daje kobiecie pewne poczucie kontroli. Należy również poinformować kobietę o konieczności jak najszybszego zgłoszenia się do lekarza w przypadku stwierdzenia jakiejkolwiek niepokojącej zmiany [34].

W często cytowanym podsumowaniu bazy Cochrane potwierdza się brak wymiernych korzyści samobadania piersi, wpływa ono natomiast na zwiększenie wykonywanych biopsji diagnostycznych [40]. W 2009 r. UPSTF opublikowało najnowsze zalecenia oparte na rzetelnej analizie badań z randomizacją, w których nie zaleca się wykonywania samodzielnego badania piersi jako badania przesiewowego [2, 20].

Badanie kliniczne piersi jest rekomendowane przez American Cancer Society w grupie kobiet ze średnim populacyjnym ryzykiem raka piersi w wieku 20.-39. roku życia co 3 lata, natomiast od 40 lat co rok w uzupełnieniu badania mammograficznego [27]. Tymczasem USPTF (2009), ACR (2008) czy eksperci z Wielkiej Brytanii - National Health Service (2011) albo nie określają wartości klinicznej tego postępowania, albo nie znajdują wystarczających dowodów, aby zalecać jako badanie przesiewowe badanie kliniczne piersi przez lekarza [2, 27]. Wreszcie, Światowa Organizacja Zdrowia (World Health Organization - WHO) rekomenduje wykonanie mammografii co 1-2 lata w grupie kobiet w wieku 50-69 lat, ale nie zaleca samobadania piersi oraz badania lekarskiego piersi jako metod skriningu [41]. Należy tu jeszcze wspomnieć, że jest mało prawdopodobne, aby wykryć w badaniu palpacyjnym zmiany mniejsze niż 0,5 cm [42]. Czułość badania klinicznego piersi określa się na 40-69\%, natomiast samobadania piersi na 12-41\% [2]. Wartość kliniczną badania lekarskiego determinuje doświadczenie badającego (praktyka), ustalenie oraz wdrażanie standaryzacji tego badania. Kliniczne badanie piersi jest istotnym i w pełni uzasadnionym postępowaniem w tych krajach, w których dostęp do mammografii jest ograniczony [2].

\footnotetext{
Piśmiennictwo

1. Didkowska J, Wojciechowska U, Zatoński W. Nowotwory w Polsce w roku 2009. Centrum Onkologii Instytut, Warszawa 2011.

2. US Preventive Services Task Force. Screening for breast cancer: U.S. Preventive Services Task Force recommendation statement. Ann Intern Med 2009; 151: 716-26.
} 
3. Matkowski R. Etiopatogeneza raka piersi. W: Markowska J (red.). Ginekologia Onkologiczna. Tom II. Urban \& Partner, Wrocław 2006.

4. Szewczyk K. Epidemiologia i profilaktyka raka piersi. W: Kornafel J (red.). Rak piersi. CMKP, Warszawa 2011.

5. El Saghir NS, Anderson BO. Breast cancer early detection and resources: Where in the world do we start? Breast 2012; 21: 423-5.

6. Horner MJ, Ries LAG, Krapcho M, et al. SEER cancer Statistics Review, 1975-2006, National Cancer Institute. Bethesda, MD: National Cancer Institute; 2009 Accessed at http://seer.cancer.gov/csr/1975_2006.

7. Narod SA. Hormonal prevention of hereditary breast cancer. Ann N Y Acad Sci 2001; 952: 36-43.

8. Marchbanks PA, Curtis KM, Mandel MG, et al. Oral contraceptive formulation and risk of breast cancer. Contraception 2012; 85: 342-50.

9. Grabrick DM, Hartmann LC, Cerhan JR, et al. Risk of breast cancer with oral contraceptive use in women with a family history of breast cancer. JAMA 2000; 284: 1791-8.

10. Fisher B, Costantino JP, Wickerham DL, et al. Tamoxifen for prevention of breast cancer: report of the National Surgical Adjuvant Breast and Bowel Project P-1 Study. J Natl Cancer Inst 1998; 90: 1371-88.

11. Waters EA, McNeel TS, Stevens WM, Freedman AN. Use of tamoxifen and raloxifene for breast cancer chemoprevention in 2010. Breast Cancer Res Treat 2012; 134: 875-80.

12. Calderon-Margalit R, Paltiel O. Prevention of breast cancer in women who carry BRCA1 or BRCA2 mutations: a critical review of the literature. Int J Cancer 2004; 112: 357-64.

13. Kauff ND, Satagopan JM, Robson ME, et al. Risk-reducing salpingo-oophorectomy in women with a BRCA1 or BRCA2 mutation. N Engl J Med 2002; 346: 1609-15.

14. Jakubowska A, Gronwald J, Lubiński J i wsp. Rola tamoksifenu u nosicielek mutacji BRCA1 w chemoprewencji dziedzicznego raka piersi. Współcz Onkol 2002; 6: 597-601.

15. Turkistani A, Marsh S. Pharmacogenomics of third-generation aromatase inhibitors. Expert Opin Pharmacother 2012; 13: 1299-307.

16. Rekomendacje PTG dotyczące wykrywania wysokiego, dziedzicznie uwarunkowanego ryzyka zachorowania na raka gruczołu sutkowego i/lub jajnika oraz opieki nad rodzinami, w których ono występuje (2004).

17. Humphrey LL, Helfand M, Chan BK, Woolf SH. Breast cancer screening: a summary of the evidence for the U.S. Preventive Services Task Force. Ann Intern Med 2002; 137: 347-60.

18. Jassem J, Bobek-Billewicz B, Krzakowski M i wsp. Rak Piersi. Zalecenia postępowania diagnostyczno-terapeutycznego w nowotworach złośliwych. www.onkologia.zalecenia.med.pl 2009.

19. Wesołowska E. Badania przesiewowe w zakresie wczesnego wykrywania raka piersi. W: Meder J (red.). Podstawy onkologii klinicznej. CMKP, Warszawa 2011.

20. Nelson HD, Tyne K, Naik A, et al. Screening for breast cancer: an update for the U.S. Preventive Services Task Force. Ann Intern Med 2009; 151: 727-37.

21. Nienartowicz E. Diagnostyka mammograficzna raka piersi. W: Kornafel J (red.). Rak piersi. CMKP, Warszawa 2011.

22. Tejerina Bernal A, Tejerina Bernal A, Rabadán Doreste F, et al. Breast imaging: how we manage diagnostic technology at a multidisciplinary breast center. J Oncol 2012; 2012: 213421.

23. Rekomendacje Zarządu Głównego PTG w sprawie profilaktyki i wczesnej diagnostyki zmian w gruczole sutkowym (23.2.2005).

24. American College of Radiology, dostępne na http://www.acr.org; Breast density bro_ACR_SBI-F.

25. Balleyguier C, Ayadi S, Van Nguyen K, et al. BIRADS classification in mammography. Eur J Radiol 2007; 61: 192-4.
26. Didkowska J. Wskaźniki zdrowotne chorób nowotworowych w Polsce na tle Europy. Onkologia w praktyce klinicznej. Wydanie specjalne 2010; 24-7.

27. Smith RA, Cokkinides V, Brooks D, et al. Cancer screening in the United States, 2010: a review of current American Cancer Society guidelines and issues in cancer screening. CA Cancer J Clin 2010; 60: 99-119.

28. Gaj P, Kluska A, Nowakowska D, et al. High frequency of BRCA1 founder mutations in Polish women with nonfamilial breast cancer. Fam Cancer 2012. [Epub ahead of print].

29. Kolb TM, Lichy J, Newhouse JH. Comparison of the performance of screening mammography, physical examination, and breast US and evaluation of factors that influence them: an analysis of 27,825 patient evaluations. Radiology 2002; 225: 165-75.

30. Lawrence WF, Liang W, Mandelblatt JS, et al. Serendipity in diagnostic imaging: magnetic resonance imaging of the breast. J Natl Cancer Inst 1998; 90: 1792-800.

31. Kriege M, Brekelmans CT, Boetes C, et al. Efficacy of MRI and mammography for breast-cancer screening in women with a familial or genetic predisposition. N Engl J Med 2004; 351: 427-37.

32. Warner E, Plewes DB, Hill KA, et al. Surveillance of BRCA1 and BRCA2 mutation carriers with magnetic resonance imaging, ultrasound, mammography, and clinical breast examination. JAMA 2004; 292: 1317-25.

33. Kuhl CK, Schrading S, Leutner CC, et al. Mammography, breast ultrasound, and magnetic resonance imaging for surveillance of women at high familial risk for breast cancer. J Clin Oncol 2005; 23: 8469-76.

34. Knutson D, Steiner E. Screening for breast cancer: current recommendations and future directions. Am Fam Physician 2007; 75: 1660-6.

35. Smith RA, Cokkinides V, Brooks D, et al. Cancer screening in the United States, 2010: a review of current American Cancer Society guidelines and issues in cancer screening. CA Cancer J Clin 2010; 60: 99-119.

36. O'Malley MS, Fletcher SW. US Preventive Services Task Force. Screening for breast cancer with breast self-examination. A critical review. JAMA 1987; 257: 2196-203.

37. Łepecka-Klusek C, Jakiel G, Krasuska ME, Stanisławek A. Breast self-examination among Polish women of procreative age and the attached significance. Cancer Nurs 2007; 30: 64-8.

38. Thomas DB, Gao DL, Ray RM, et al. Randomized trial of breast self-examination in Shanghai: final results. J Natl Cancer Inst 2002; 94: 1445-57.

39. Hackshaw AK, Paul EA. Breast self-examination and death from breast cancer: a meta-analysis. Br J Cancer 2003; 88: 1047-53.

40. Kösters JP, Gøtzsche PC. Regular self-examination or clinical examination for early detection of breast cancer. Cochrane Database Syst Rev 2003; (2): CD003373.

41. World Health Orgaznization Screeniong for Breast Cancer. Geneva: World Health Organization, 2009. www.who.int/cancer/detection/breastcancer/en/index.html

42. Reintgen D, Berman C, Cox C, et al. The anatomy of missed breast cancers. Surg Oncol 1993; 2: 65-75.

Prawidłowe odpowiedzi do Testowego programu edukacyjnego dotyczącego znaczenia profilaktyki pierwotnej i wtórnej raka piersi, zamieszczonego w numerze 3/2012 Przeglądu Menopauzalnego:

1. d; 2. b; 3. d; 4. d; 5. a; 6. d; 7. d; 8. d; 9. d; 10. d; 11. d; 12. b. 